\title{
Levels of Heavy Metals in Soil Sample from Active Automobile Workshops in Benin City
}

\author{
Anegbe Bala ${ }^{1}$, Okuo James Majebi ${ }^{2}$, Okieimen Felix Ebhodaghe ${ }^{3}$, Ugbune Ufuoma ${ }^{4}$, \\ Emina Rosemary Anwuli ${ }^{5}$ \\ ${ }^{1}$ Department of Basic and Industrial Chemistry, Western Delta University, Oghara, Delta State, Nigeria \\ ${ }^{2}$ Environmental Analytical Research Laboratory, Department of Chemistry, University of Benin, Benin City, Nigeria \\ ${ }^{3}$ GeoEnvironmental and Climate Change, Department of Chemistry, University of Benin, Benin City, Nigeria \\ ${ }^{4}$ Department of Chemistry, Delta State College of Education, Mosogar, Nigeria \\ ${ }^{5}$ Department of Chemistry, Chrisland University, Abeokuta, Nigeria
}

Email address:

bala.anegbe@wdu.edu.ng (A. Bala),james.Okuo@uniben.edu (O.J. Majebi)

\section{To cite this article:}

Anegbe Bala, Okuo James Majebi, Okieimen Felix Ebhodaghe, Ugbune Ufuoma, Emina Rosemary Anwuli. Levels of Heavy Metals in Soil Sample from Active Automobile Workshops in Benin City. International Journal of Environmental Chemistry.

Vol. 3, No. 1, 2019, pp. 7-17. doi: 10.11648/j.jjec.20190301.12

Received: May 1, 2018; Accepted: February 21, 2019; Published: March 14, 2019

\begin{abstract}
The evaluation of heavy metals contamination of soils as a means of monitoring the status of the environment for the good of the ecosystem is crucial. Benin city was subdivided into four zones (south east SE, south west SW, north east NE and north west NW) In this study, top soil (TS) and distance top soil (DTS) samples from three hundred and thirty-nine auto repair workshops in Benin City, Nigeria were assessed for physico-chemical properties and heavy metals (HMs), using standard methods. The main soil properties $(\mathrm{pH}$, cation exchange capacity, total organic carbon and particle sizes) were determined for a network of representative sampling sites. The results shows that the average levels of the heavy metals (excluding Fe) in soil samples from within and $30 \mathrm{~m}$ away from the automobile workshops in the various zones are 143.1 (88.6), 118.6 (86.9), 129.1 (79.2) and 143.3 (113.0) for SE, SW, NE and NW respectively (the values in bracket represents DTS). When compared with mean concentrations for other cities. The results revealed higher concentrations of heavy metals in topsoil samples than in $30 \mathrm{~m}$ away from the epicentre samples. The samples from North West and South East part of the city had higher $\mathrm{Cr}, \mathrm{Ni}, \mathrm{Pb}$, and $\mathrm{Zn}$ contents than samples from the other Locations. All the heavy metals show significant differences in their means across the two sampling locations (TS and DTS). The correlation analysis showed that all the heavy metals were significantly correlated with each other. The principal component analysis produced only one component which accounted for $69.414 \%$ of the total variation between the heavy metals.
\end{abstract}

Keywords: Heavy Metals, Auto-repair Workshops, Soils, Concentrations

\section{Introduction}

During the last decades of the twentieth century there was an awareness of the importance of the soil as an environmental component and recognition of the need to maintain or improve its capacity to allow it to perform its various functions [1]. At the same time there was a confirmation that the soil is not an inexhaustible resource, and if used improperly or poorly managed, its characteristics can be lost in a short period of time, with limited opportunities for regeneration [2]. However, the final disposal of potentially toxic residues in the soil has become a practical and inexpensive alternative and can cause alterations in the arthropod community [3]. Heavy metals are considered as one of the most serious pollutants in the environment due to their toxicity, persistence and bioaccumulation. These elements can bio-accumulate in plants and animals eventually making their way to humans through food chain [4]. Soil samples represent an excellent media to monitor heavy metal pollution because anthropogenic heavy metals are usually deposited in top soils. In Nigeria, as in many other countries, heavy metals contamination is 
widespread. Pollution arising from the disposal of used engine oil is one of the environmental problems in Nigeria and is more widespread than crude oil pollution [1]. The prevalent mode of indiscriminate disposal of these spent engine oils in the environment calls for urgent attention. Contamination results from mishandling, deliberate disposal, spilling and leakage of petroleum products, such as gasoline, lubricating oils, diesel fuel, heating oil's, used or spent engine oils. A survey of Benin City the capital of Edo State, Nigeria indicates that there are about five hundred and seven automobile workshops scattered all over the city from which used engine oils, lubricating oils and other solvents containing heavy metals are indiscriminately dumped or spilled on every available space by artisans in the business of auto-repairs [4]. The local utilization of engine oil in Benin City has increased in recent time this is due to the upsurge in the number of vehicles due to ever-increasing demand for personal vehicles, most of which are used "Tokunbo" vehicles and other machines that makes use of these lubricants. These unguided practices have worsened the rate at which used engine oils spread and contaminate the soils and water around the town. Studies in auto repair workshop sites have been carried out by many researchers in different Cities. [6-9]. However, many of these researchers focused on the study of the heavy metals contamination in soil within the epicenter without recourse to their horizontal migration. In addition, information or data about the basis for the choice of mechanic workshops in other to have representative samples are not available. Benin City is housing two major auto-spare parts markets (Uwelu and Evbareke spare parts market both in North West part of the city). There is mounting evidence that heavy metals have been slowly accumulating on automobile site impacted by these artisans [7]. The soils of Benin City automobile workshops have been least characterize in terms of heavy metals. Thus the aim of this research is to obtain a representative soil sample and evaluate the contribution of the activities of automobile workshops to heavy metals load in soils, as well as their horizontal migration from different zones in Benin City.

\section{Materials and Methods}

\subsection{Study Area}

The study area is Benin City, a transitory town and a fast growing City with a population of $1,147,188$ according to 2006 population census. Benin City is the administrative capital of Edo State. Small-scale enterprises/artisan workshops dot the landscape of the City. Figure 1 shows map with three hundred and thirty-eight sampled automobile workshops. No waste management practice is done on these workshops. Wastes are indiscriminately discarded on the soils. Benin City is located on the Rain Forest of Edo States of Nigeria.
A survey carried out to enumerate automobile workshops in Benin City revealed five hundred and seven (507) active workshops in the metropolis. The City was divided into four zones; Northwest (NW), Northeast (NE), Southwest (SW) and Southeast (SE) to allow a closer examination of the activities within each workshop location in the zones. It was observed that i) a typical automobile workshop accommodated a variety of artisans; mechanics, panel-beater, battery-charger and spray-painter and ii) several semiautonomous automobile workshops operated in clusters each specializing in one-or-more brands of vehicle: cars by brand and/or make, lorries by make etc. It was seldom to find a workshop with lorries and cars. On account of proximity of workshops, activities and duration of operation of the workshops, soil samples were taken from three hundred and thirty-eight (338) workshops. The number of samples to be analysed were further reduced to 40 in the NW zone, 15 in the SE zone, 10 each in the NE and SW zones based on the number of workshops in the zones and the cluster density of workshops in the zones. Top soil samples were collected at the epicentre of the automobile workshop (TS), at 30m from the epicentre (DTS) and at a control site farmland in the Faculty of Agriculture, University of Benin. The standard chain of custody for handling soil samples was followed in the transfer of the samples to the laboratory. The soil samples were then air-dried, crushed/ground in a porcelain mortar and sieved through a $2 \mathrm{~mm}$ mesh. The soil samples with $<2 \mathrm{~mm}$ size were retained for analysis.

\subsection{Determination of the Physico-chemical Properties and Total Heavy Metals in Soil Samples}

The $\mathrm{pH}$ and the CEC were determined as described by [10]. The hydrometer method described by [11] was used in evaluating the particle size, while the method described by [4] was use to evaluate the total organic carbon. The pseudototal levels of $\mathrm{Ni}, \mathrm{Cr}, \mathrm{V}, \mathrm{Fe}, \mathrm{Cd}$ and $\mathrm{Pb}$ in soil were extracted by acid digestion in accordance with the USEPA method described by [12].

\section{Results and Discussions}

Soil $\mathrm{pH}$ is an important index that controls various physicochemical reactions in soil. Most metals tend to be less mobile in soils with high $\mathrm{pH}$ as they form insoluble complexes [10]. The mean $\mathrm{pH}$ of the soil samples in the zones ranged 5.78-6.16 showing slightly acidic property, some of the values were lower than the $\mathrm{pH}$ of the soil from the control site (6.14). Presence of residual hydrocarbon spills and oil may have had some direct impact in lowering the $\mathrm{pH}$ of the soil samples. It is also more likely that production of organic acid by microbial metabolism is responsible for the difference in $\mathrm{pH}$ [13]. 


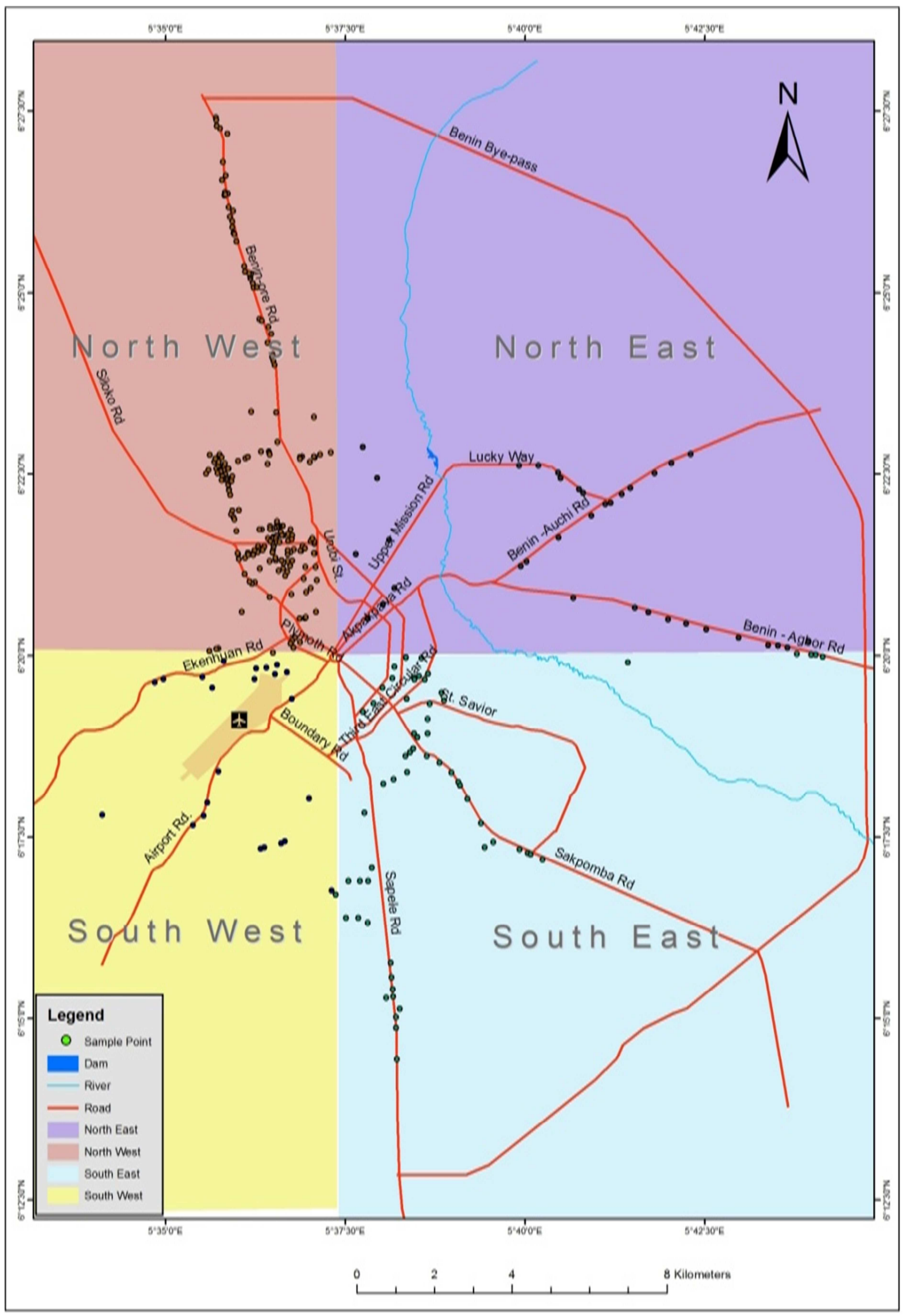

Soil Sampling Protocol and Preparation

Figure 1. Map with Three Hundred and Thirty-Eight Sampled Automobile Workshops. 
Table 1. Summary of Average Values of Some Physico-Chemical Properties of Soil Samples from Automobile Workshops in Benin City.

\begin{tabular}{|c|c|c|c|c|c|c|c|}
\hline \multirow{3}{*}{\multicolumn{2}{|c|}{ Location of automobile workshop }} & \multicolumn{6}{|c|}{ Physico-chemical properties } \\
\hline & & \multirow{2}{*}{ pH } & \multirow{2}{*}{ CEC $\left(\mathrm{mg} \cdot \mathrm{kg}^{-1}\right)$} & \multirow{2}{*}{ TOC (\%) } & \multicolumn{3}{|c|}{ Texture } \\
\hline & & & & & Sand & Clay & Silt \\
\hline \multirow{3}{*}{ North West } & Mean & 5.96 & 292.51 & 37.06 & 78.28 & 14.86 & 6.10 \\
\hline & Min & 5.30 & 243.30 & 17.54 & 62.40 & 7.30 & 2.10 \\
\hline & $\operatorname{Max}$ & 6.50 & 309.33 & 59.33 & 90.40 & 22.40 & 16.60 \\
\hline \multirow[t]{3}{*}{ North East } & Mean & 5.96 & 279.78 & 27.39 & 75.41 & 14.05 & 7.37 \\
\hline & Min & 5.30 & 239.10 & 20.54 & 70.10 & 10.40 & 5.40 \\
\hline & $\operatorname{Max}$ & 6.50 & 286.60 & 36.66 & 82.30 & 17.30 & 11.20 \\
\hline \multirow[t]{3}{*}{ South West } & Mean & 6.16 & 283.57 & 16.96 & 78.25 & 13.41 & 6.33 \\
\hline & Min & 5.70 & 264.30 & 8.33 & 75.10 & 11.40 & 3.80 \\
\hline & Max & 6.70 & 300.30 & 24.28 & 82.30 & 16.40 & 8.70 \\
\hline \multirow[t]{3}{*}{ South East } & Mean & 5.78 & 292.39 & 41.79 & 79.50 & 12.82 & 6.09 \\
\hline & Min & 5.20 & 280.20 & 31.19 & 70.10 & 10.20 & 3.80 \\
\hline & Max & 6.80 & 300.30 & 53.88 & 85.20 & 15.62 & 8.20 \\
\hline control & & 6.14 & 385.80 & 4.30 & 74.50 & 15.30 & 8.20 \\
\hline
\end{tabular}

According to [14], the soil CEC is a measure of the negative site of the soil colloid in which the positive charge cation act on. The cation exchange capacity (CEC) is a direct contribution from the clay and organic matter contents of soil. In this study, the average CEC values ranged between 279.78 and $292.51 \mathrm{mgkg}^{-1}$ (Table 1). These values are relatively low. The low values were attributed to high sandy nature of the soil, a soil low in CEC content but high in sand is susceptible to high leaching because the retention power of heavy metals in its soil is low $[15,16]$. The relatively high levels of average total organic carbon (16.96-41.79\%) in the soils of the auto-mechanic workshops in these zones when compared to the control (Table 1) indicated the possible presence of organic matter content which normally increases following the addition of carbonaceous substances as was the case in this study due to the presence of used oil and other carbonated fluid in the auto-mechanic workshops. According to [17], this might cause an increase in the presence of soil micro-organisms which are in the business of breaking down organic compounds in soils. This observation clearly shows that a significant quantity of the oil has undergone appreciable decomposition or degradation process. Texture reflects the particle size distribution of the soil and, thus the content of fine particles like oxides and clay. These compounds are important adsorption media for heavy metals in soils. From the textural analysis, the workshop soil samples have low clay and silt content and a high sand fraction (75.41-79.50\% average) in the soil. The silt and clay fractions ranged $6.09-7.37$ and $12.82-14.86 \%$ average respectively. In general, all soil examined contained less than
$20 \%$ average clay content. Clay soil retains high amount of metals when compared to sandy soil. Thus it is predictable that the auto-mechanic workshops soils under investigation are susceptible to leaching.

\subsection{Heavy Metals in Soil Samples from Automobile Workshops in NW Zone}

The soil samples from auto-mechanic workshops in North West zone of Benin revealed elevated levels of these heavy metals $(\mathrm{Cd}, \mathrm{Cr}, \mathrm{Fe}, \mathrm{Ni}, \mathrm{Pb}$ and $\mathrm{V}$ ) (Table 2). The results showed that heavy metals concentrations in the soil samples were higher in the auto-mechanic workshops than the control. According to [18], engine oil and other transmission fluids collect heavy metals such as lead, cadmium, zinc, iron and copper when an automobile engine is running and they remain in the used oil. When it is discharged, it increases the concentration of heavy metals in soils and was responsible for the higher concentration in the auto-mechanic soils than the control which is not exposed to any waste engine oil. A similar result has been reported by [18], from Okigwe, Orji and Nekede mechanic villages in Imo state, Nigeria, and by [19], from auto-mechanic villages in Ibadan, Nigeria. These elevated levels observed may be connected with the large amounts of waste engine oil and other chemical fluids discharged in the workshops, metal scrap deposits, welding and other wastes that are potential sources of heavy metals. Generally, the concentrations of the heavy metals were high (Table 2). This is an indication that these heavy metals are the primary contaminant in the auto-mechanic workshop soils.

Table 2. Descriptive Statistics of Heavy Metals $\left(\mathrm{mgkg}^{-1}\right)$ in the Soil Samples from Automobile Workshops in North West Zone of Benin City.

\begin{tabular}{|c|c|c|c|c|c|c|c|c|c|c|c|c|}
\hline \multirow{2}{*}{$\begin{array}{l}\text { Sample } \\
\text { Description }\end{array}$} & \multirow{2}{*}{$\begin{array}{l}\text { Cd } \\
\text { TS }\end{array}$} & \multicolumn{3}{|c|}{$\mathrm{Fe}$} & \multicolumn{2}{|l|}{$\mathbf{P b}$} & \multicolumn{2}{|l|}{$\mathrm{Ni}$} & \multicolumn{2}{|l|}{ V } & \multicolumn{2}{|l|}{$\overline{\mathrm{Cr}}$} \\
\hline & & DTS & TS & DTS & TS & DTS & TS & DTS & TS & DTS & TS & DTS \\
\hline Mean & 6.7 & 5.3 & 2015.9 & 1827.8 & 28.1 & 22.4 & 27.6 & 20.5 & 31.9 & 26.2 & 49.0 & 38.6 \\
\hline Median & 6.6 & 4.9 & 2041.7 & 1874.6 & 26.4 & 20.1 & 28.0 & 19.8 & 31.5 & 26.6 & 49.3 & 40.0 \\
\hline Standard Deviation & 1.8 & 1.8 & 309.3 & 444.4 & 8.0 & 8.8 & 4.8 & 5.0 & 5.3 & 7.5 & 11.9 & 13.1 \\
\hline Sample Variance & 3.4 & 3.3 & 95672.5 & 197505.5 & 64.2 & 77.4 & 23.2 & 24.8 & 27.9 & 55.8 & 140.5 & 171.2 \\
\hline Range & 8.4 & 7.1 & 1342.7 & 1487.3 & 29.5 & 36.0 & 18.8 & 19.2 & 20.2 & 26.7 & 46.9 & 54.0 \\
\hline Minimum & 2.3 & 2.5 & 1323.7 & 1105.0 & 16.1 & 12.4 & 18.8 & 12.3 & 19.7 & 13.0 & 30.3 & 13.3 \\
\hline Maximum & 10.7 & 9.6 & 2666.4 & 2592.3 & 45.6 & 48.3 & 37.6 & 31.5 & 39.9 & 39.7 & 77.2 & 67.3 \\
\hline
\end{tabular}


Iron had the highest concentration in the soils sampled and such levels of iron concentration have also been reported by [20], for automobile workshops in Osun state. The observation here confirms that most soils contain appreciable quantities of iron. In this zone iron (Fe), has a mean of 2015.9 and $1827.8 \mathrm{mg} / \mathrm{kg}$ for TS and DTS respectively (Table 2). The increase in concentration of $\mathrm{Fe}$ in some of the sites from TS to DTS, could be attributed to the evidence from molecular spectroscopy that heavy metals (HMs) form strong bonds with specific functional groups of humic substances (HSs) from the organic matter contaminants (OCs), carboxylate (-COO$)^{-}$, phenolic and sulphur-hydryl (-SH) functional groups [21]. These may also be as a result of heavy metal-ligand complex formation and competition to destabilize it and forming of new complexes with the HM cation, [4].

Lead $(\mathrm{Pb})$ occurs naturally in all soils in concentrations ranging from 1 to $200 \mathrm{mg} \cdot \mathrm{kg}^{-1}$ with a mean value of $15 \mathrm{mg} \cdot \mathrm{kg}^{-1}$ [22]. Soil $\mathrm{Pb}$ concentrations greater than $1.0 \mathrm{mg} / \mathrm{kg}$ generally indicate a local source of pollution [23]. Concern for $\mathrm{Pb}$ concentrations in auto-mechanic workshop soils whose meanconcentration was up to 28.1 and $22.4 \mathrm{mg} / \mathrm{kg}$ for TS and DTS (Table 2) may therefore arise principally due to the fact that most of the studied auto-mechanic workshop could also be identified as play ground or near residential areas where children play about freely, and for children, ingestion of contaminated soil is the most significant pathway for $\mathrm{Pb}$ [1]. The mean concentration of $\mathrm{Pb}$ was higher than $15.1 \mathrm{mg} \cdot \mathrm{kg}^{-1}$ reported by [19], as well as $14.13 \mathrm{mg} . \mathrm{kg}^{-1}$ reported by [24]. The mean $\mathrm{Pb}$ values in the study area were however lower than the value (76.92 mg. $\mathrm{kg}^{-1}$ ) reported by [25], $47.8 \mathrm{mg} \cdot \mathrm{kg}^{-1}$ reported by [26], as well as USEPA [27] and NEPCA [28] relative relaxed criteria of $400 \mathrm{mg} \cdot \mathrm{kg}^{-1}$ and $300 \mathrm{mg} \cdot \mathrm{kg}^{-1}$ respectively. This may be due to lower amount of used automobile batteries which are a ready source of lead, though this is gradually being phased out. Some exceptionally high values of lead have also been reported in literatures and most were in one way or the other connected to manufacturing sites of vehicle batteries. Elevated lead values are due to on-going lead deposition in soils within the mechanic workshops and its consequent retention in the soil upper layers. All the sampled soils however have values lower than $85 \mathrm{mg} . \mathrm{kg}^{-1}$ which is the target value set by DPR [29]. The mean values for $\mathrm{Cr}$ are 49.0 and $38.6 \mathrm{mg} \cdot \mathrm{kg}^{-1}$ for TS and DTS respectively (Table 2). All thevalues obtained for TS and DTS were found to be higher than the values of CCME [30] assessment criteria (20.00 mg. $\mathrm{kg}^{-1}$ ) for chromium. The values were however close to DPR target value $\left(100 \mathrm{mg} \cdot \mathrm{kg}^{-1}\right)$ for $\mathrm{Cr}$. The marked difference between them and the control (Table 6) suggest contamination due to automobile artisan activities. Chromium though an essential element may be toxic at high levels. Chromium presents some risks to human health since chromium can be accumulated on skin, lungs, muscles fat, and it accumulates in liver, dorsal spine, hair, nails and placenta where it is traceable to various heath conditions [31]. Cadmium was detected in all the soils but the concentration in the control soil was below detection limit. According to [32], the presence of Cadmium could be due to the dumping of PVC plastics, nickel-cadmium batteries, motor oil and disposal sludge in the auto-mechanic workshops. The presence of cadmium in automobile waste dump soils have also been reported by [33]. The mean concentrations of cadmium in TS and DTS are 6.7 and 5.3 mg. $\mathrm{kg}^{-1}$. The critical soil total contents of $\mathrm{Cd}$ according to environmental regulations of several countries are $0.3 \mathrm{mg} . \mathrm{kg}^{-1}$ in both Denmark and Finland; 0.4 in Czech Republic; 0.5 in Canada; 0.8 in both Netherlands and Switzerland; 0.4 for clay soils and 1.5 for sandy soils in Germany; 0.1 in Ireland; and $0.2 \mathrm{mg} \cdot \mathrm{kg}^{-1}$ in Eastern Europe. The obtained data in the present work indicated that the total $\mathrm{Cd}$ contents in all the studied samples exceed the permissible critical limits (limit of contamination) of all the above countries. The high $\mathrm{Cd}$ levels obtained from the soil samples of auto-mechanical workshop sites may be due to the motor vehicle repair such as body work, painting, soldering, brake fluid, engine oils, shear off from metal plating, leachates from used oils and old tyres frequently burnt on these sites, corrosion of metal, batteries and metal parts such as radiators and indiscriminate dumping of waste products are likely source of cadmium [1]. Cadmium has no constructive purpose in human body. [34], pointed out that the nickel content in soil can be as low as $0.2 \mathrm{mg} \cdot \mathrm{kg}^{-1}$ or as high as $450 \mathrm{mg} \cdot \mathrm{kg}^{-1}$, although the average is about $20 \mathrm{mg} / \mathrm{kg}$ which is consistent with the concentration obtained for the auto mechanic workshops soils. Nickel is known to accumulate in plants and with intake of too large quantities of Nickel from plants grown on nickel rich soils (such as tea, beans, vegetables), there are higher chances of developing cancers of the lung, nose, larynx and prostrate as well as respiratory failures, birth defects and heart disorders [35 and 34]. Nickel metal pollution of the soil also has negative side effects on vegetation as confirmed by [36], where they showed a phytotoxic effect of soil collected from abandoned mechanic village and reported that the soil depressed and inhibited plant growth. The mean concentrations of nickel in TS and DTS are 27.6 and $20.5 \mathrm{mg} . \mathrm{kg}^{-1}$ respectively. A very low concentration of $0.2 \pm 0.00-0.31 \pm 0.00 \mathrm{mg} \cdot \mathrm{kg}^{-1}$ of nickel was found in the control sample.

The elevated levels of $\mathrm{Ni}$ and $\mathrm{V}$ were not surprising as both have been reported to be major constituent of petroleum. Vanadium in the control sample was below detection limit for TS and DTS. The highest concentration of V in NW is 39.9 mg. $\mathrm{kg}^{-1}$ while the lowest is $19.7 \mathrm{mg} \cdot \mathrm{kg}^{-1}$ (Table 2). The marked difference between the values reported for nickel and vanadium in the contaminated site and the control suggest contamination due to automobile artisan activities.

The results given in Table 2 indicate that the average total level of heavy metals in soil samples from automobile workshops in the NW zone of Benin City is $143.3 \mathrm{mg} \cdot \mathrm{kg}^{-1}$; the distribution patter of which (Figure 2) shows that $\mathrm{Cr}$ (34.2\% of the average total level of heavy metals) is the predominant heavy metal while $\mathrm{Cd}(4.7 \%$ of the average total level of heavy metals) showed the lowest value. 


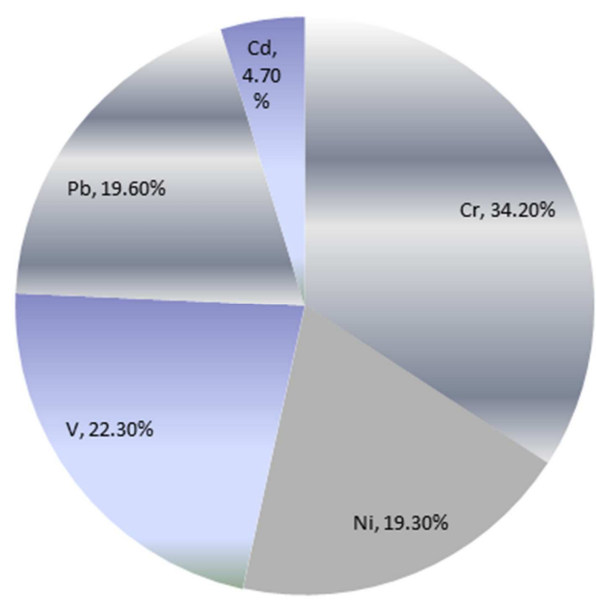

Figure 2. Distribution Pattern of Heavy Metals in Soil from Automobile Workshops in the NW Zone of Benin City.

The average total levels of $\mathrm{Pb}, \mathrm{Ni}$ and $\mathrm{V}$ are about the same order of magnitude and contributed $19.6 \%, 19.3 \%$ and $22.3 \%$ respectively to the average total level of heavy metals in soil from automobile workshops in the NW zone of Benin City.

The average total level of heavy metals in soil samples taken at a distance of $30 \mathrm{~m}$ from the epicentres of the workshops in the NW zone is $113.0 \mathrm{mg} \cdot \mathrm{kg}^{-1}$ and represent about $79 \%$ of the value for soil taken within (epicentre) of the workshops. This result indicates a profuse dispersion of heavy metals from within the automobile workshops to soil contiguous to the locations of the workshops. The distribution pattern of heavy metals in these soil samples (Figure 3) is similar to that in the soil samples taken from the epicientres of the automobile workshop and supports the notion of profuse spatial contamination of contiguous soils from activities within the automobile workshops.

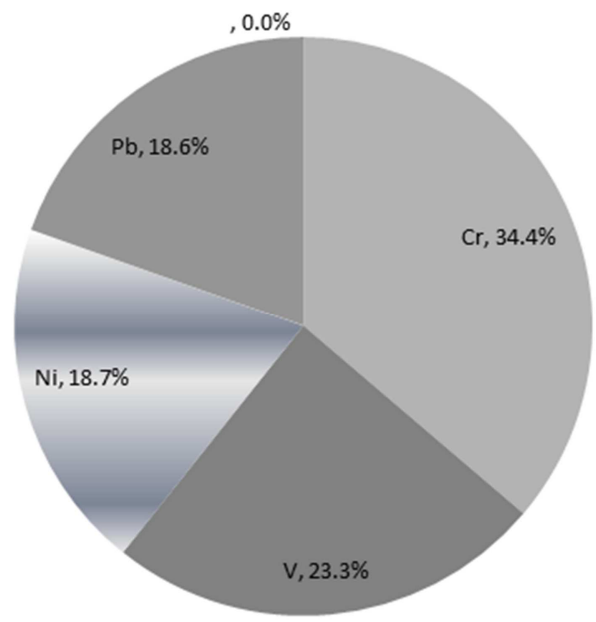

Figure 3. Distribution Pattern of Heavy Metals in Soil Samples Taken $30 \mathrm{~m}$ from the Epicientres of Automobile Workshops in NW Zone of Benin City.

\subsection{Heavy Metals in Soil Samples from Automobile Workshops in SE Zone}

The mean concentrations of HMs in auto-mechanic workshop soil samples in the SE zone (Table 3) was found to be in agreement with that found in NW Zone. This zone account for about $20.1 \%$ of the total number of mechanic workshops in Benin City. However, the zone has the highest number of heavy duty automobile workshops mainly along the Benin-Auchi and Benin-Agbor axes of the metropolis. The NNPC petroleum products depot and Guiness PLC Brewery, Bendel Brewery (now not in operation) are located in this zone.

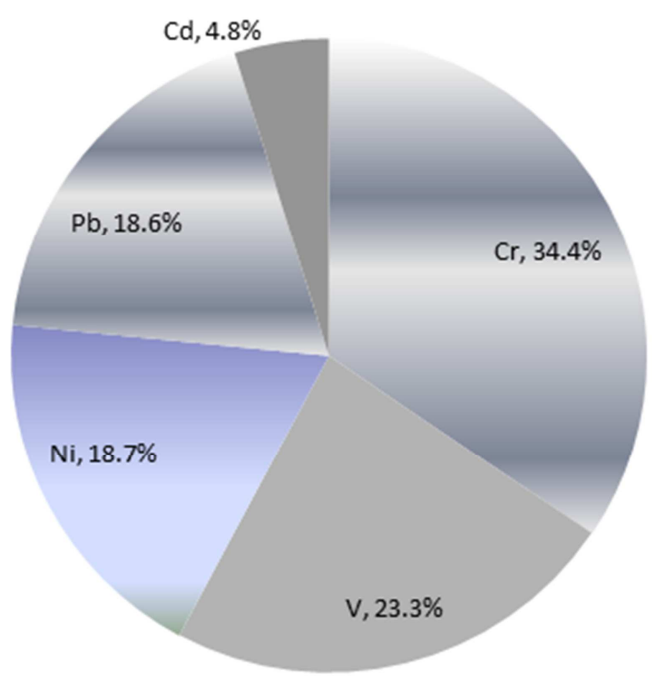

Figure 4. Distribution Pattern of Heavy Metals in Soil from Automobile Workshops in the SE Zone of Benin City.

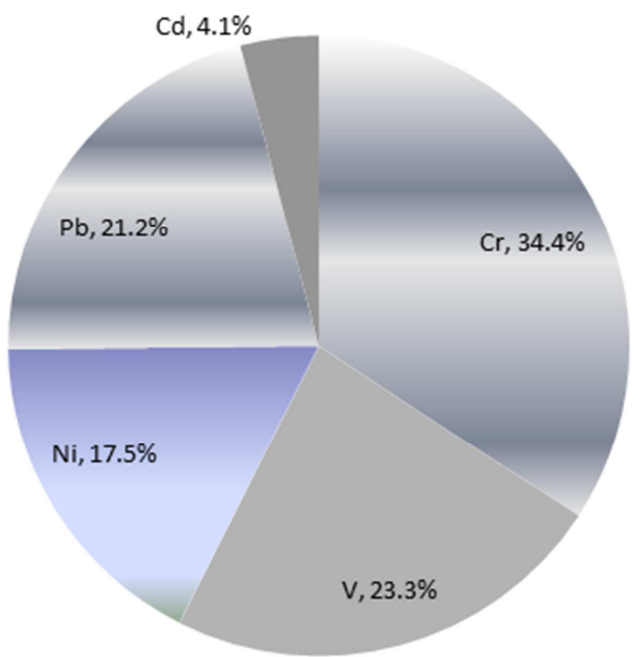

Figure 5. Distribution Pattern of Heavy Metals in Soil Samples Taken at 30 $m$ from the Epicentres of Automobile Workshops in the SE Zone of Benin City.

Table 3. Descriptive Statistics of Heavy Metals $\left(\mathrm{mgkg}^{-1}\right)$ in Soil Samples from Automobile Workshops in South East Zone of Benin City.

\begin{tabular}{|c|c|c|c|c|c|c|c|c|c|c|c|c|}
\hline \multirow{2}{*}{ Sample Description } & \multicolumn{2}{|l|}{ Cd } & \multicolumn{2}{|l|}{$\mathrm{Fe}$} & \multicolumn{2}{|l|}{$\mathbf{P b}$} & \multicolumn{2}{|l|}{$\mathbf{N i}$} & \multicolumn{2}{|l|}{$\mathbf{V}$} & \multicolumn{2}{|l|}{$\mathrm{Cr}$} \\
\hline & TS & DTS & TS & DTS & TS & DTS & TS & DTS & TS & DTS & TS & DTS \\
\hline Mean & 6.90 & 3.60 & 1781.70 & 1406.30 & 26.70 & 18.80 & 26.90 & 15.50 & 33.40 & 20.90 & 49.20 & 29.80 \\
\hline
\end{tabular}




\begin{tabular}{|c|c|c|c|c|c|c|c|c|c|c|c|c|}
\hline \multirow{2}{*}{ Sample Description } & \multicolumn{2}{|l|}{ Cd } & \multicolumn{2}{|l|}{$\mathrm{Fe}$} & \multicolumn{2}{|l|}{$\mathbf{P b}$} & \multicolumn{2}{|l|}{$\mathrm{Ni}$} & \multicolumn{2}{|l|}{$\mathbf{V}$} & \multicolumn{2}{|l|}{$\mathrm{Cr}$} \\
\hline & TS & DTS & TS & DTS & TS & DTS & TS & DTS & TS & DTS & TS & DTS \\
\hline Median & 6.50 & 3.60 & 1653.30 & 1383.30 & 24.40 & 16.30 & 27.10 & 15.00 & 33.10 & 21.20 & 45.00 & 28.10 \\
\hline Standard Deviation & 1.70 & 1.00 & 473.60 & 324.80 & 7.00 & 6.30 & 5.00 & 1.90 & 8.80 & 5.40 & 16.60 & 14.10 \\
\hline Sample Variance & 3.00 & 0.90 & 224323.90 & 105480.60 & 48.70 & 39.90 & 24.60 & 3.60 & 77.20 & 29.40 & 274.60 & 199.10 \\
\hline Range & 5.90 & 3.80 & 1451.30 & 1245.30 & 22.00 & 19.00 & 15.90 & 7.00 & 31.50 & 19.10 & 55.10 & 46.10 \\
\hline Minimum & 3.70 & 1.80 & 1266.70 & 913.30 & 18.30 & 11.20 & 19.10 & 13.70 & 20.80 & 10.90 & 25.30 & 13.00 \\
\hline Maximum & 9.50 & 5.70 & 2718.00 & 2158.70 & 40.30 & 30.20 & 35.10 & 20.70 & 52.30 & 30.10 & 80.40 & 59.20 \\
\hline
\end{tabular}

The average total level of heavy metals in soil samples from automobile workshops in this zone of Benin City is $143.1 \mathrm{mg} \cdot \mathrm{kg}^{-1}$, while the value for soil samples taken $30 \mathrm{~m}$ from the epicentres of the workshops is $88.6 \mathrm{mgkg}^{-1}$ and represents $61 \%$ of average value of soils samples taken from the epicentresof the workshops. The distribution patterns of the heavy metals in the soil samples taken from within the workshop and from a distance of $30 \mathrm{~m}$ from the epicentres of the automobile workshops are given in Figures 4 and 5 respectively.

It would seem from these results that the heavy metals in the automobile workshops in this zone are less dispersed in the contiguous soil than in the North West zone. It is thought that differences in soil physico-chemical properties would contribute the reduced mobility of the heavy metals.

\subsection{Heavy Metals in Soil Samples from Automobile Workshops in NE Zone}

The average total levels of the metals from automobile workshops in the NE zone of Benin City are given in Table 4. The average total levels of the heavy metals in soil samples from within the workshops (129.1 mg. $\left.\mathrm{kg}^{-1}\right)$ and for soil samples taken $30 \mathrm{~m}$ from the workshops $\left(79.2 \mathrm{mg} \cdot \mathrm{kg}^{-1}\right)$ are lower than the values reported for soil samples from the NW and SE zones of Benin City. It would appear that the heavy metals in soil samples from automobile workshops in this zone are dispersed to the contiguous soil to about the same extent as in the SE zone.

The distribution pattern of the heavy metals in the soil samples from automobile workshops in this zone of Benin City are shown in Figures 6 and 7 for samples taken from within the workshops and from a distance of $30 \mathrm{~m}$ from the workshops respectively.

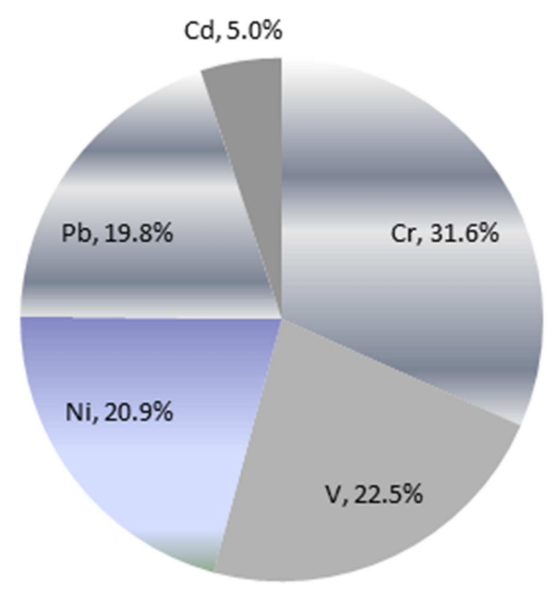

Figure 6. Distribution Pattern of Heavy Metals in Soil Samples from Automobile Workshops in SE Zone of Benin City.

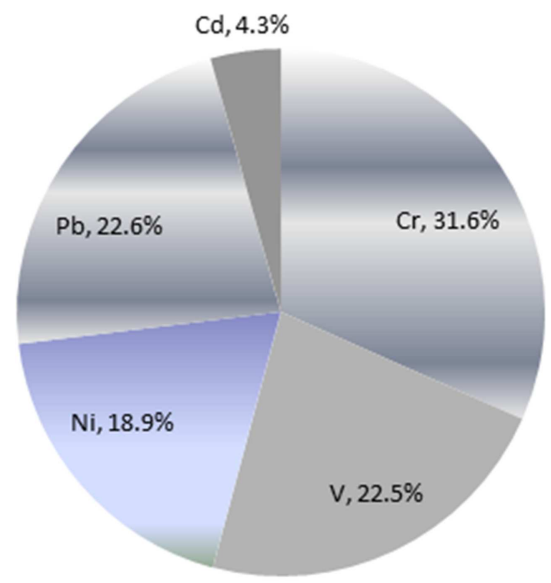

Figure 7. Distribution Pattern Of Heavy Metals In Soil Samples Taken $30 \mathrm{~m}$ from Automobile Workshops in SE Zone of Benin City.

Table 4. Descriptive Statistics of Heavy Metals $\left(\mathrm{mg} \mathrm{kg}^{-1}\right)$ in Soil Samples from Automobile Workshops in North East Zone of Benin City.

\begin{tabular}{|c|c|c|c|c|c|c|c|c|c|c|c|c|}
\hline \multirow{2}{*}{ Sample Description } & \multicolumn{2}{|l|}{ Cd } & \multicolumn{2}{|l|}{$\mathrm{Fe}$} & \multicolumn{2}{|l|}{$\mathbf{P b}$} & \multicolumn{2}{|l|}{$\mathbf{N i}$} & \multicolumn{2}{|l|}{$\mathbf{V}$} & \multicolumn{2}{|l|}{$\mathrm{Cr}$} \\
\hline & TS & DTS & TS & DTS & TS & DTS & TS & DTS & TS & DTS & TS & DTS \\
\hline Mean & 6.50 & 3.40 & 1822.10 & 1394.80 & 25.60 & 17.90 & 27.10 & 15.00 & 29.10 & 17.30 & 40.80 & 25.60 \\
\hline Median & 7.10 & 3.70 & 1673.30 & 1391.70 & 26.60 & 16.50 & 27.50 & 14.80 & 30.70 & 20.90 & 41.10 & 26.90 \\
\hline Standard Deviation & 2.00 & 1.10 & 408.00 & 268.30 & 7.00 & 6.70 & 5.40 & 2.00 & 8.00 & 5.10 & 16.00 & 12.70 \\
\hline Sample Variance & 4.00 & 1.30 & 166449.40 & 72011.40 & 49.00 & 44.60 & 29.40 & 4.00 & 64.00 & 26.20 & 256.10 & 161.30 \\
\hline Range & 5.90 & 3.80 & 1104.70 & 1046.70 & 22.00 & 19.00 & 15.90 & 7.00 & 26.70 & 16.40 & 47.80 & 40.80 \\
\hline Minimum & 3.70 & 1.60 & 1366.70 & 913.30 & 18.30 & 11.70 & 19.10 & 13.70 & 20.80 & 10.90 & 25.30 & 13.00 \\
\hline Maximum & 7.50 & 5.70 & 2471.30 & 1960.00 & 41.30 & 30.20 & 35.10 & 20.70 & 47.50 & 27.30 & 73.10 & 53.80 \\
\hline
\end{tabular}


Table 5. Descriptive Statistics of Heavy Metals $\left(\mathrm{mgkg}^{-1}\right)$ in Soil Samples from Automobile Workshops in South West Zone of Benin City.

\begin{tabular}{|c|c|c|c|c|c|c|c|c|c|c|c|c|}
\hline \multirow{2}{*}{ Sample Description } & \multicolumn{2}{|l|}{ Cd } & \multicolumn{2}{|l|}{$\mathbf{F e}$} & \multicolumn{2}{|l|}{$\mathbf{P b}$} & \multicolumn{2}{|l|}{$\mathbf{N i}$} & \multicolumn{2}{|l|}{$\mathbf{V}$} & \multicolumn{2}{|l|}{$\mathrm{Cr}$} \\
\hline & TS & DTS & TS & DTS & TS & DTS & TS & DTS & TS & DTS & TS & DTS \\
\hline Mean & 6.00 & 3.20 & 1696.80 & 1463.50 & 24.10 & 17.80 & 25.30 & 14.90 & 25.50 & 17.00 & 37.70 & 34.00 \\
\hline Median & 6.00 & 3.40 & 1670.00 & 1450.00 & 24.00 & 20.10 & 26.00 & 17.30 & 32.10 & 15.90 & 49.30 & 33.10 \\
\hline Standard Deviation & 0.90 & 0.60 & 182.60 & 258.70 & 4.70 & 4.70 & 3.60 & 4.10 & 8.20 & 5.30 & 12.20 & 11.60 \\
\hline Sample Variance & 0.80 & 0.40 & 33347.20 & 66914.50 & 22.20 & 22.00 & 12.90 & 17.00 & 66.90 & 27.80 & 148.60 & 134.10 \\
\hline Range & 3.10 & 1.90 & 461.70 & 950.00 & 16.30 & 11.80 & 12.00 & 13.00 & 27.30 & 12.00 & 35.70 & 31.10 \\
\hline Minimum & 4.20 & 3.20 & 1466.70 & 966.70 & 20.30 & 15.20 & 18.50 & 12.40 & 18.60 & 13.00 & 35.00 & 20.30 \\
\hline Maximum & 7.20 & 5.10 & 1928.30 & 1916.70 & 36.60 & 27.00 & 30.50 & 25.50 & 45.90 & 25.00 & 70.70 & 51.50 \\
\hline
\end{tabular}

\subsection{Soil Samples from Automobile Workshops in SW Zone}

Table 5 gives the heavy metals in soil samples from automobile workshops in the SW zone of Benin City. The average total level of the heavy metals in soil samples taken at a distance of $30 \mathrm{~m}$ from the epicentres of the workshop (86.9 $\mathrm{mgkg}^{-1}$ ) is about $73 \%$ of the average value of the heavy metals in soils samples from within the workshops $\left(118.6 \mathrm{mgkg}^{-1}\right)$.

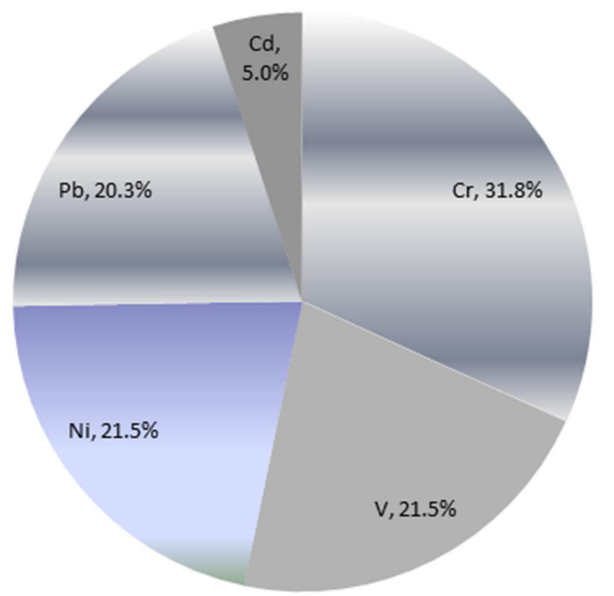

Figure 8. Distribution Pattern of Heavy Metals in Soil Samples from Automobile Workshops in SW Zone of Benin City.

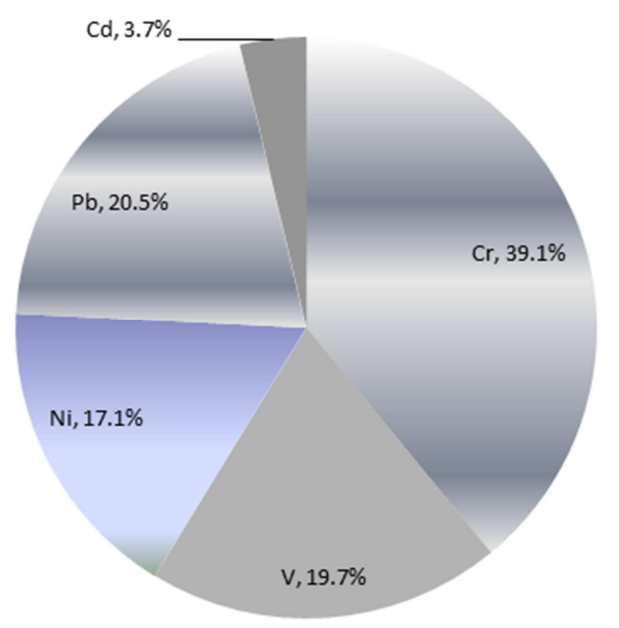

Figure 9. Distribution Pattern of Heavy Metals in Soil Samples Taken $30 \mathrm{~m}$ from Automobile Workshops in SW Zone of Benin City.

It would appear from these results that the soil from this zone (SW zone) is the least impacted by the activities of automobile workshops. The distribution pattern of the heavy metals in the soil samples (Figures 8 and 9) reveal similar trend in the relative properties of the heavy metals in the soil: $\mathrm{Cr}$ showing the highest average total levels and $\mathrm{Cd}$ the least values.

Table 6. Heavy Metals $\left(\mathrm{mgkg}^{-1}\right)$ in Soil Samples from Control Site.

\begin{tabular}{|c|c|c|c|c|c|c|c|c|c|c|c|c|}
\hline \multirow{2}{*}{ Control } & \multicolumn{2}{|l|}{$\mathrm{Cd}$} & \multicolumn{2}{|l|}{$\mathrm{Fe}$} & \multicolumn{2}{|l|}{$\mathbf{P b}$} & \multicolumn{2}{|l|}{$\mathbf{N i}$} & \multicolumn{2}{|l|}{$\mathbf{V}$} & \multicolumn{2}{|l|}{$\mathrm{Cr}$} \\
\hline & TS & DTS & TS & DTS & TS & DTS & TS & DTS & TS & DTS & TS & DTS \\
\hline Mean & $<0.01$ & $<0.01$ & $110 \pm 2.02$ & $110 \pm 0.87$ & $0.32 \pm 0.10$ & $0.32 \pm 0.11$ & $0.29 \pm 0.00$ & $0.2 \pm 0.00$ & $<0.01$ & $<0.01$ & $0.22 \pm 0.01$ & $0.20 \pm 0.05$ \\
\hline
\end{tabular}

The average levels of the heavy metals in soil samples from within the automobile workshops in the various zones are given in Table 7 .

Table 7. Average Total Levels of Heavy Metals $\left(\mathrm{mg}_{\mathrm{k}} \mathrm{kg}^{-1}\right)$ in Soil Samples from within Automobile Workshops in Benin City.

\begin{tabular}{ll}
\hline Zone & $\mathbf{M}_{\text {Total }}\left(\mathbf{m g}_{\mathbf{k g}} \mathbf{~}^{\mathbf{1}}\right)$ \\
\hline SE & $143.1(88.6)$ \\
SW & $118.6(86.9)$ \\
NE & $129.1(79.2)$ \\
NW & $143.3(113.0)$ \\
Sum & $534.1(367.1)$ \\
\hline
\end{tabular}

Values in parentheses are for soil samples taken at a distance of $30 \mathrm{~m}$ from the epicentre of the workshop

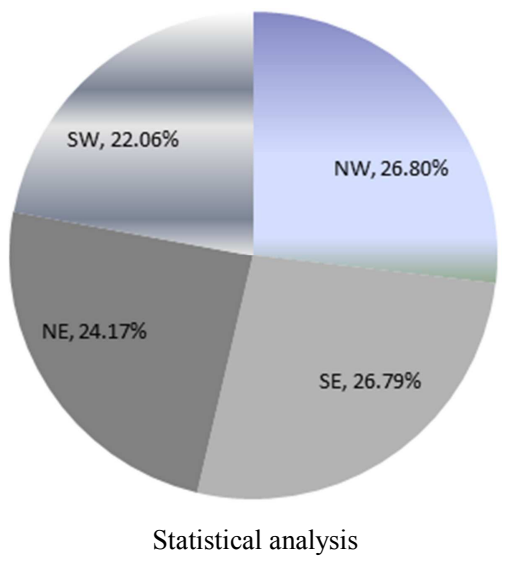

Figure 10. Contribution Automobile Workshops in Various Zones to the Overall Environmental Burden of Heavy Metals in Soil in Benin City. 
Figure 10 shows the near-even contribution of automobile workshops from the different zones to the overall environmental burden of heavy metals in soil in Benin City.

\subsection{T-Test for Total Metal Concentration}

All the heavy metals: cadmium $(\mathrm{t}=7.389, p=0.000)$, Iron $((\mathrm{t}=4.052, p=0.000)$, Lead $(\mathrm{t}=5.300, p=0.000)$, Nickel $(\mathrm{t}$ $=11.185, p=0.000)$, Vanadium $(\mathrm{t}=7.742, p=0.000)$, and Chromium $(\mathrm{t}=6.523, p=0.000)$ shows significant differences in their means across the two sampling locations as shown in Table 8.

Table 8. T- Test for Total Metal Concentration.

\begin{tabular}{|c|c|c|c|c|c|c|c|c|}
\hline & & \multicolumn{7}{|c|}{ t-test for Equality of Means } \\
\hline & & \multirow[t]{2}{*}{$\mathbf{t}$} & \multirow[t]{2}{*}{ Df } & \multirow{2}{*}{$\begin{array}{l}\text { Sig. (2- } \\
\text { tailed) }\end{array}$} & \multirow{2}{*}{$\begin{array}{l}\text { Mean } \\
\text { Difference }\end{array}$} & \multirow{2}{*}{$\begin{array}{l}\text { Std. Error } \\
\text { Difference }\end{array}$} & \multicolumn{2}{|c|}{$\begin{array}{l}\text { 95\% Confidence Interval of } \\
\text { the Difference }\end{array}$} \\
\hline & & & & & & & Lower & Upper \\
\hline \multirow{2}{*}{ Cadmium } & Equal variances assumed & 7.389 & 148 & .000 & 2.0683840 & .2799245 & 1.5152188 & 2.6215492 \\
\hline & Equal variances not assumed & 7.389 & 147.955 & .000 & 2.0683840 & .2799245 & 1.5152175 & 2.6215506 \\
\hline \multirow{2}{*}{ Iron } & Equal variances assumed & 4.052 & 148 & .000 & 263.4890982 & 65.0195012 & 135.0025994 & 391.9755971 \\
\hline & Equal variances not assumed & 4.052 & 144.444 & .000 & 263.4890982 & 65.0195012 & 134.9765228 & 392.0016736 \\
\hline \multirow{2}{*}{ Lead } & Equal variances assumed & 5.300 & 148 & .000 & 6.4584380 & 1.2185929 & 4.0503492 & 8.8665268 \\
\hline & Equal variances not assumed & 5.300 & 147.444 & .000 & 6.4584380 & 1.2185929 & 4.0502744 & 8.8666017 \\
\hline \multirow{2}{*}{ Nickel } & Equal variances assumed & 11.185 & 148 & .000 & 8.5892636 & .7679497 & 7.0717010 & 10.1068263 \\
\hline & Equal variances not assumed & 11.185 & 147.926 & .000 & 8.5892636 & .7679497 & 7.0716947 & 10.1068326 \\
\hline \multirow{2}{*}{ Vanadium } & Equal variances assumed & 7.742 & 148 & .000 & 8.8095146 & 1.1378329 & 6.5610175 & 11.0580117 \\
\hline & Equal variances not assumed & 7.742 & 147.478 & .000 & 8.8095146 & 1.1378329 & 6.5609519 & 11.0580773 \\
\hline Chromium & Equal variances assumed & 6.523 & 148 & .000 & 14.3373746 & 2.1978566 & 9.9941407 & 18.6806085 \\
\hline
\end{tabular}

\subsection{Correlation for Total Metal Concentration}

The correlation analysis showed that all the heavy metals were significantly correlated with each other. However, the highest correlation exist between Vanadium and Chromium ( $\mathrm{r}$ $=0.765$ ).

The strong positive linear relationship between the heavy metals shows that an increase in the concentration of one heavy metal in the soil samples may result in an increase in the concentration of the other heavy metals present in the soil samples, however, since correlation does not imply causation, the presence of one heavy metal in the soil sample will not necessarily guarantee the presence of another heavy metal.

Table 9. Correlation for Total Metal Concentration.

\begin{tabular}{|c|c|c|c|c|c|c|c|}
\hline & & Cadmium & Iron & Lead & Nickel & Vanadium & Chromium \\
\hline \multirow[t]{2}{*}{ Cadmium } & $\begin{array}{l}\text { Pearson Correlation } \\
\text { Sig. (2-tailed) }\end{array}$ & 1 & & & & & \\
\hline & $\mathrm{N}$ & 150 & & & & & \\
\hline \multirow{3}{*}{ Iron } & Pearson Correlation & $.718^{* *}$ & 1 & & & & \\
\hline & Sig. (2-tailed) & .000 & & & & & \\
\hline & $\mathrm{N}$ & 150 & 150 & & & & \\
\hline \multirow[t]{2}{*}{ Lead } & Sig. (2-tailed) & .000 & .000 & & & & \\
\hline & $\mathrm{N}$ & 150 & 150 & 150 & & & \\
\hline \multirow{3}{*}{ Nickel } & Pearson Correlation & $.598^{* *}$ & $.626^{* *}$ & $.507^{* *}$ & 1 & & \\
\hline & Sig. (2-tailed) & .000 & .000 & .000 & & & \\
\hline & $\mathrm{N}$ & 150 & 150 & 150 & 150 & & \\
\hline \multirow{2}{*}{ Vanadium } & Pearson Correlation & $.602^{* *}$ & $.725^{* *}$ & $.535^{* *}$ & $.672^{* *}$ & 1 & \\
\hline & $\mathrm{N}$ & 150 & 150 & 150 & 150 & 150 & \\
\hline \multirow{3}{*}{ Chromium } & Pearson Correlation & $.595^{* *}$ & $.694^{* *}$ & $.717^{* *}$ & $.551^{* *}$ & $.765^{* *}$ & 1 \\
\hline & Sig. (2-tailed) & .000 & .000 & .000 & .000 & .000 & \\
\hline & $\mathrm{N}$ & 150 & 150 & 150 & 150 & 150 & 150 \\
\hline
\end{tabular}

**. Correlation is significant at the 0.01 level (2-tailed).

\subsection{Principal Component Analysis}

The principal component analysis produced only one component which accounted for $69.414 \%$ of the total variation between the heavy metals as shown in Table 10. 
Table 10. Total Variance for Total Metal Concentration.

\begin{tabular}{lllllll}
\hline \multirow{2}{*}{ Component } & \multicolumn{2}{l}{ Initial Eigenvalues } & & \multicolumn{2}{l}{ Extraction Sums of Squared Loadings } \\
\cline { 2 - 6 } & Total & \% of Variance & Cumulative\% & Total & \% of Variance & Cumulative\% \\
\hline 1 & 4.165 & 69.414 & 69.414 & 4.165 & 69.414 & \\
2 & .580 & 9.673 & 79.087 & & \\
3 & .469 & 7.825 & 86.912 & & \\
4 & .406 & 6.763 & 93.676 & & \\
5 & .223 & 3.709 & 97.385 & & \\
6 & .157 & 2.615 & 100.000 & & & \\
\hline
\end{tabular}

Extraction Method: Principal Component Analysis

\section{Conclusion}

The elevated levels of $\mathrm{Fe}, \mathrm{Cd}, \mathrm{Cr}, \mathrm{Pb}, \mathrm{Ni}$ and $\mathrm{V}$ in the vicinity of automobile workshops in Benin City are of environmental and public health concern. The concentration levels of heavy metals were noted to be affected by sampling distance. The high level of sand suggested that the soil will have weak surface aggregation, high rate of water infiltration, metal ions would be leached to the subsoil and thereafter into ground water to cause pollution. All the heavy metals showed significant differences in their mean concentration levels across the two sampling locations. A knowledge of the total concentration of these heavy metals through soil analysis (as indicator) could be considered as a starting point for evaluating the degree of pollution as investigated in this study. Above all, mechanic workshop owners should be given stringent rules to operate with full compliance in order to minimize the level of heavy metals introduced to the environment.

\section{References}

[1] Anegbe, B., Okuo, J. M. and Okieimen, F. E. (2016). The impact of inorganic and organic pollutants in soil from the vicinity of mechanic workshops in Benin City. International Journal of Chemical Studies. 4(3):106-112.

[2] Nortcliff, S. (2002) Standardisation of soil quality attributes. Agriculture, Ecosystems and Environment, 88: 161-168.

[3] VanStraalen, (2004) The use of soil invertebrates in ecological surveys of contaminatedsoils. Developments in Soil Science, 29: 159-195.

[4] Anegbe, B., Okuo, J. M. and Okieimen, F. E. (2017). Characterization and remediation of soil co-contaminated by heavy metals and petroleum hydrocarbons. Mostvirtue Benin City, Edo State, Nigeria.

[5] Odoh, R., Oko, O. J., Kolawale, S. A. and Oche, E. O. (2011) A comparative study of the heavy metal content of drinking water in different storage vessels. International Journal of Modern Chemistry, 5(3): 166-180.

[6] Ipeaiyeda, A. R. and Dawodu, M. (2008) Heavy metals contamination of topsoil and dispersion in the vicinities of reclaimed auto-repair workshops in Iwo, Nigeria. Bulletin of Chemical Society of Ethiopia, 22(3): 339-348.

[7] Idugboe, S. O., Tawari-Fufeyin, M. A. A. (2014) Soil pollution in two auto-mechanic villages in Benin City, Nigeria.
Journal of Environmental Science, Toxicology and Food Technology 8(1): 9-14.

[8] Odjegba, V. J. and Sadiq, A. O. (2002) Effects of spent engine oil on the growth parameters, chlorophyll and protein levels of Amaranthus hybridus L. The Environmentalist, 22: 23-28.

[9] Ololade, I. A., Lajide, L. and Amoo, I. A. (2007) Enrichment of Heavy Metals in Sediments as Pollution Indicator of the Aquatic Ecosystem. Pakistan Journal of Scientific and Industrial Research, 50: 27-35.

[10] Anegbe, B., Okuo, J. M., Ewekay, E. O. and Ogbeifun, D. E. (2014) Fractionation of lead-acid battery soil amended with biochar. Bayero Journal of Pure and Applied Sciences, 7(2):36-43.

[11] Asagba, E. U., Okiemien, F. E. and Osokpor, J. (2007). Screening and speciation of heavy metal contaminated soil from an automobile spare-parts market. Chemical Speciation and Bioavailability, 19(1): 9-15.

[12] Khodadoust, A. P., Reddy, K. R. and Maturi, K. (2004) Removal of nickel and phenanthrene from kaolin soil using different extractants, Environmental Engineering Science, 21(6): 691-704.

[13] Okoro, D., Oviasogie, P. O. and Oviasogie, F. E. (2011) Soil quality assessment 33 months after crude oil spillageand clean-up. Chemical Speciation and Bioavailability, 23 (1): 1-6.

[14] Hazelton, P. A. and Murphy, B. W. (2007) Interpreting Soil Test Results: What do all the Numbers Mean? CSIRO Publishing, Collingwood, pp17.

[15] Ugbune, U. and Okuo, J. (2011) Sequential Fractionation and Distribution of Heavy Metals in Soil from Battery Work Sites. Nigeria Journal of Applied Science.29: 132-141.

[16] Okiemen, F. E., Emwanta, D. O. and Odikayo, O. O. (2012). Stabilization of heavy Metals in CCA Contaminated Soil. International Journal of Applied Environmental Sciences, 7(2): 215-232.

[17] Osuji, L. C. and Nwoye, I. (2007) An appraisal of the impact of petroleum hydrocarbons on soil fertility: The Owaza experience. African Journal of Agricultural Research, 2(7): $318-324$

[18] Nwachukwu, M. A., Feng, H., and Alinnor, J. (2010) Assessment of heavy metalsin soil and their implications within and around mechanic villages, International Journal of Environmental Science and Techology, 7(2): 347-358.

[19] Adelekan, B. A. and Abegunde, K. D. (2011) Heavy metal contamination of soil and ground water at automobile mechanic villages in Ibadan, Nigeria. International Journal of Physical Sciences, 6(5): 1045-1058. 
[20] Abidemi, O. O. (2011) Levels of $\mathrm{Pb}, \mathrm{Fe}, \mathrm{Cd}$ and $\mathrm{Co}$ in Soils of Automotive Workshop in Osun State, Nigeria. Journal of Applied Sciences and Environmental Management, 15(2): 279-282.

[21] Zhao, P., Tan, Y., Guo, Y., Gu, X., Wang, X. and Zhang, Y. (2013) Interaction of tetracycline with $\mathrm{Cd}(\mathrm{II}) \mathrm{Cu}(\mathrm{II})$ and $\mathrm{Pb}$ (II) and their cosorption behavior in soils. Environmental Pollution, 180: 206-213.

[22] Chirenje, T., Ma, L. Q., Clark, C. and Reeves, M. (2003). Cu, $\mathrm{Cr}$ and As distribution in soils adjacent to pressure-treated decks, fences and poles. Journal of Environmental Pollution, 124: 407-417.

[23] Kabata-Pendias, A. and Pendias, H. (1992) Trace Elements in Soils and Plants. 2nd edition, CRC Press, Boca Raton. Pp 365.

[24] Babatunde, O. A., Oyewale, O. A. and Steve, P. I. (2014) Bioavailability of Trace Element in Soils around Nnpc Oil Depot Jos Nigeria. Journal of Environmental Science, Toxicology and Food Technology, 8: 47-56.

[25] Okunola, O. J., Uzairu, A., and Ndukwe, G. (2007) Levels of trace metals in soiland vegetation along major and minor roads in metropolitan city of Kaduna, Nigeria, African Journal of Biotechnology, 6(14): 1703-1709.

[26] Sitkol, L. R., Zawisza, B., Jurczyk, J., Buhl, F. and Zielonka, U. (2004) Determination of High $\mathrm{Zn}$ and $\mathrm{Pb}$ Concentrations in Polluted Soils Using Energy-Dispersive X-ray Fluorescence Spectrometry. Polish Journal of Environmental Studies, 13(1): 91-96.

[27] United States Environmental Protection Agency, USEPA (2008) Allowable Limits for Lead in Soil. www.epa.gov/lead/pubs/leadhaz.htm.

[28] National Environment Protection Council of Australia, NEPCA (2010) Limits of Heavy Metals in Soils. Available online at www.newzealand.govt.nz.

[29] Department of Petroleum Resources (2002) Environmental guidelines and Standards for the petroleum industries in Nigeria Depaertment of Petroleum Resources, Ministry of Petroleum and Mineral Resources, Abuja, Nigeria.

[30] CCME (1999) Canadian Council of Ministers of the Environment, Canadiansoil quality guidelines for the protection of environmental and human health: Summary Tables In: Canadian environmental quality guidelines, 1999. Canadian Council of Ministers of the Environment, Winnipeg. Pp. 131-147.

[31] Reyes-Gutiérrez, L. R., Romero-Guzmán, E. T., Cabral-Prieto, A., Rodríguez- Castillo, R. (2007). Characterization of Chromium in Contaminated SoilStudied by SEM, EDS, XRD and Mössbauer Spectroscopy. J. Miner. Mater. Characterization Eng. 7(1): 59-70.

[32] Ebong, G. A., Akpan, M. M. and Mkpene, V. N. (2008) Heavy metal content of municipal and rural dumpsite soils and rate of accumulation by Carica papaya and Talinum triangulare in Uyo Nigeria. E-Journal of Chemistry, 5(2): 281290.

[33] Uba, S., Uzairu, A., Harrison, G. F. S., Balarabe, M. L. and Okunola, O. J. (2008) Assessment of heavy metals bioavailability in dumpsites of Zaria metropolis, Nigeria. African Journal of Biotechnology, 7(2): 122-130.

[34] Lenntech, W. T. (2009) Chemical Properties, Health and Environmental Effects of Copper. Lenntech WaterTreatment and Purification Holding B. V. www. Lenntech. comeriodic/element/cu.htm.

[35] Duda-Chodak, A. and Blaszczyk, U. (2008) The Impact of Nickel on HumanHealth. Journal Elementology, 13(4): 685696.

[36] Anoliefo, G. O., Isikhuemhen, O. S. and Agbuna, S. O. (2001) Small scale industrial village in Benin City Nigeria: Establishment failure and phytotoxicity assessment of soils from the abandoned site. Water, Air and Soil Pollution, 131: 169-183. 